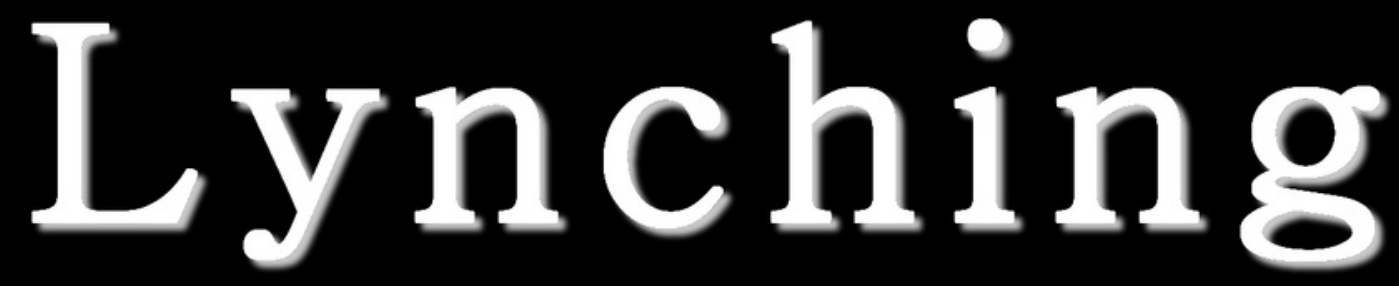

The lynching of blacks in the United States of America - Photographs as historical memories

Authors: Giovanni Corvino, Claudia Bommino

Submitted: 26. November 2017

Published:

27. November 2017

Volume:

4

Issue:

Affiliation:

Languages:

Keywords:

DOI:

6

Turin University

English

lynching, photographs, United States of America 10.17160/josha.4.6.363 


\title{
The lynching of blacks in the United States of America - Photographs as historical memories
}

Corvino G.B. (corresponding author)

MA in Social Work and Social Policies - Turin University

MA in Criminological and Forensic Psychology - Turin University

giovanni.corvino@edu.unito.it

Bommino C.

MA in Criminological and Forensic Psychology - Turin University

claudia.bommino@edu.unito.it

\begin{abstract}
According to the literature, photographs of human lynching had an important role in supporting the practice and the predisposition to photographing. This act was globally common. The aim of this brief paper is to understand why photographs of blacks lynching by whites were so important in the United States of America, especially in the South.
\end{abstract}

Keywords lynching, photographs, United States of America.

The term "lynching" refers to a wide range of behaviors, from hangings performed by small groups of people to the most ritualized executions; all performed in the presence of wealthy crowds (Brundage, 1993; Waldrep, 2002; Garland, 2008). Many claim that this expression originates from the activities of Charles Lynch, a Virginia peace judge who in 1782 was indemnified by an act of the Virginia Assembly for having illegally fined in 1780 and imprisoned some conservatives. According to Albert Matthews, although there was no evidence that linked Charles Lynch to those acts, since 1817, they were designated as the expression of the "Law of Lynch". Some suggested that the term was derived from the name of Lynch's Creek, a place known for being in 1768 the seat of a so-called " regulators" " meetings in South Carolina. Although the purpose of these meetings was to provide solutions to the perceived lack of a regular criminal justice administration, they actually mobilized numerous acts of violence against whoever was suspected of conservatism (Segrave, 2010). The most commonly used lynching method was by hanging, which we can 
consider as a real murder, but there are also cases of stoning, beatings and firearms (Zimring, 2009). Around the end of the 1770s, the United States spread the tendency to pronounce sentences and punishments by "lynching law". In the early years, the punishment inflicted usually was limited to practices such as busting (covering someone's pitch and feathers or similar practices) out soon, lynching became an expression of the will to inflict only one kind of punishment on the victim: a capital castigation (Segrave, 2010). This is because the crime committed by a black, and therefore belonging to a lower and unruly class, was seen by the whites as a challenge to their values and, as such, required a firm opposition.

Several researchers examined the causes of lynching at regional, national and local levels and the results were remarkably similar; it seems that lynching episodes have been greater in times of higher political and / or economic competition between racial or ethnic groups (Soule, 1992).

Historians and sociologists also agree that the economic condition of the South in general, and in Georgia in particular, is a crucial factor for the rise of the lynching of blacks at the end of the eighteenth century (Beck and Tolnay, 1990; Goodwyn, 1976; Rochester, 1943, Olzak, 1990). The increased migration to the southern cities, due to the cotton economy and the discriminatory credit system in place, generated a greater competition over the limited resources. These forces were the main causes for determining the need of an "effective" political presence which could provide "actual" aids to the fast-growing impoverishment of the farmers (Soule, 1992). With the modification of the plantation system in the South, two fundamental changes occurred in the southern economy. First, when African Americans started to buy pieces of land to cultivate, they began competing with white farmers for a share of the cotton market. Second, the blacks migrated to the southern productive sectors, competed with the white workers for the same jobs. These two factors led to a greater competition for resources in the agricultural and manufacturing sectors. As a result, whites were frightened by the growing blacks labor force and by their greater weight — even politically — due to their economic strength that was increasing (James, 1988).

Although the theory of economic competition seems to be one of the most illustrative of the lynching phenomenon of blacks in the United States (Soule, 1992), not all lynching communicated at the same time the same meanings nor they performed all the functions that were identified during the various analyzes on the theme: each event took place and meant something at one time and in a specific space.

Lynching victims, at the time of their capture, were described as "infidel" or "inhuman", underlining the supremacy of the white population compared to the black one. Some journalists described the victims as frantic and agitated, so lacking in self-control which instead characterized the members of the crowds (Young, 2005). 
Newspapers frequently provided meaning to the class, emphasizing the fact that members of the crowd came from all spheres of social life and acted as a group united in the pursuit of a common purpose, thus legitimizing the acts of violence committed by them ( Wood, 2005). It follows that the image of the lynching that the press proposed was strongly influenced by racial considerations (Wasserman, 1998). The increasingly widespread tendency to narrate lynching episodes, describing the details as well, undoubtedly affected the creation of a wider culture of tolerance and tacit participation in such events (Hale, 1998; Young, 2005).

The visual lynching representations, in particular the photographs of the crowds and victims taken during or immediately after the violence, replicated the lynching narratives enriching them with harsh visual elements. All of it offered support to the white supremacy and also to spread a sense of white solidarity, which in turn — justified and encouraged lynching (Wood, 2005).

The number of photographs remaining over time represent only a small portion of the total number of lynchings that were executed and there is no way to accurately determine how many of these were photographed (Taft, 1938). Surely there could have been thousands of them that went lost or destroyed or that have not yet been recovered; but the uniformity between existing photographs indicates that the tendency to photograph this act was quite common (Segrave, 2010). Photographs acquired a cultural power because they were realized, distributed and embedded within a series of conventions and assumptions at the end of last century. Since the mid-nineteenth century, photography had been essentially linked to modern rationalism and empiricism, becoming an incarnation of the scientific and objective gaze of modernity, thanks to its ability to extract the subject from the subjective perspective of the observer; it created the illusion of an objective and non-mediated vision, a transparent reflection of reality (Slater, 1994).

Unlike oral narratives and reconstructions, photography has not changed over time, proving to be more authentic and accurate than other forms of evidence. It was the most significant sign of modernity, the only one capable of satisfying the spectator's request for accuracy and the presence of graphic details. In addition, the visual reproduction of lynching through photography served to support white supremacist ideologies by normalizing and enhancing violence (Young, 2005). Watching them along with a number of other images available in our daily life, especially those associated with entertainment or commercial advertising, photos of lynching and postcards representing acts of violence seemed to be a reasonable, and even gratifying, phenomenon of modern consumerism (Goldsby, 1998).

Lynching photos were initially produced and disseminated in those areas where the event occurred and were purchased primarily by members of the crowd who attended, admirers or amateur photographers. Although the photographers did not directly participate in the violence, they 
recorded the event as external journalists or commentators. They initially took these photos and then contributed to the mass consumption of them, as they were bought by the white locals; but also they printed celebratory booklets as souvenirs or postcards to be sent to sympathizers of that practice. The "audience" of these images was thus conceived as relatively narrow and contained. Before 1930, newspapers rarely had published these photographs, even when they had access (Wood, 2005).

The confidence that the Americans at the end of the last century had for photography did not only relate to the alleged objectivity of it. The photographs had a personal meaning for the people, they picked them up in albums, hanged them on the walls, or kept them as personal memories; not only because they were related to a lived experience, but because they were able to evoke or even create profound feelings connected to that experience. The lynching images worked in some way as the other souvenirs that the viewers collected after the act, such as rope pieces, body parts, braces and charcoal, totemic relics that allowed collectors to feel an emotional connection with the event (Segrave, 2010).

In a world that has placed considerable emphasis on the outward appearance and behaviors as markers of the character of individuals, photographs have been regarded as having a mystical quality thanks to the ability to immortalize expressions, postures, gestures and other indicators of the state of affairs that the human eye would not be able to recognize; people have even believed that the image could reveal the soul (Trachtenberg, 1989).

In this context we can observe images of strong-minded and resolute white men alongside the bodies of weak black men. In these photos, white perpetrators become one body, there are men and women, young and old, but their differences, though still visible, are obscured by the common purpose they pursue.

Photographs were proofs, but they had never been put to the service of the law as they had never been used as useful elements to legally prosecute perpetrators.

Later in the years, some changes occurred: when the NAACP was formed in 1909, it began collecting lynching photos in order to undertake its campaign against lynching and in 1912 published several photographs on "The Crisis".

Other periodicals, in support of the black community, began publishing these photos to publicize the atrocities that occurred in the South of the United States of America.

The Chicago Defender in 1917, for example, published a photo of the head of Ells Persons, who was burned to death in Memphis (Tennessee) for assassinating a white teenager.

It is not known how the photo was obtained, in any case to show it in order to denounce what had happened, transformed the original intent of that photograph by building an alternative social 
memory of the event: no black person, murderer or accused of any other offense, would be alive. Although these photos had very strong content, they represent a key testimony to denouncing the atrocities that the Afro-American community has had to endure and are still undergoing today under various forms of racism.

\section{Acknowledge}

We thank Paola Melloni for observations that improved the article.

\section{References}

Beck E.M. e Tolnay S. (1990), The Killing Fields of the Deep South: The Market for Cotton and the Lynching of Blacks, 1882-1930, American Sociological Review 55:526.

Brundage W.F. (1993), Lynching in the New South. Georgia and Virginia, 1880-1930, Urbana.

Garland D. (2008), Abuso Penale ed Eccedenza di Significato - I linciaggi come tortura pubblica nell'America del Ventesimo Secolo, trad. it. in Criminalia. Annuario di scienze penalistiche (3), pp. $29-52$.

Goldsby J.D. (1998), After Great Pain: The Cultural Logic of Lynching and the Problem of Realist Representation in America, 1882-1922, Yale University.

Goodwyn J. (1976), Democratic Promise, Oxford University Press.

Hale G.E. (1998), Making Whiteness. The Culture of Segregation in the South, 1890-1940, New York.

James D.R. (1988), The Transformation of the Southem Racial State: Class and Race Detenninants of Local State Structures, American Sociological Review 53:191-208.

Olzak S. (1990), The Political Context of Competition: Lynching and Urban Racial Violence, 18821914, Social Forces 69:395-421.

Rochester A. (1943), The Populist Movement in the United States, Intemational Publishers.

Segrave K. (2010), Lynchings of Women in the United States The Recorded Cases, 1851-1946, McFarland.

Soule A.S. (1992), Populism and Black Lynching in Georgia, 1890-1900, Social Forces, Volume 71, Issue 2, pp. 431-449.

Slater D. (1994), Photography and Modern Vision, 219-20 Routledge, New York. 
Taft R. (1938), Photography and the American Scene, 384-98, Dover Publications, New York.

Trachtenberg A. (1989), Reading American Photographs: Images As History-Mathew Brady to Walker Evans, Farrar, Straus and Giroux.

Waldrep C. (2002), The Many Faces of Judge Lynch. Extralegal Violence and Punishment in America, New York.

Wasserman I.M. (1998), "Media Rhetoric and Images of Lynching in the Nineteenth and Twentieth Centuries”. Michigan Sociological Review 12 (68-94).

Wood A.L. (2005), Lynching Photography and the Visual Reproduction of White Supremacy, American Nineteenth Century History, Vol. 6, No. 3, September 2005, pp. 373-399.

Young H. (2005), The Black Body as Souvenir in American Lynching, The Johns Hopkins University Press, Theatre Journal, Vol. 57, No. 4, pp. 639-657.

Zimring F.E. (2009), La Pena di Morte: le Contraddizioni Del Sistema Penale Americano, il Mulino, Bologna. 